\title{
BCL2 Gene Translocation
}

National Cancer Institute

\section{Source}

National Cancer Institute. BCL2 Gene Translocation. NCI Thesaurus. Code C38176.

A cytogenetic abnormality that refers to any translocation involving the BCL2 gene. 